\title{
Adding Another Level \\ Individual Responses to Globalization and Government Welfare Policies
}

\author{
LENA SCHAFFER AND GABRIELE SPILKER*
}

\begin{abstract}
$L$ iterature on the compensation hypothesis overwhelmingly concentrates on either the macro or micro level of the relationship between globalization and welfare spending. This paper explicitly addresses this shortcoming by using individual citizens and country-specific characteristics in a hierarchical model framework. We start by examining individual's context-conditional reactions to actual economic globalization and welfare generosity; after which, we make the effect of actual economic globalization (welfare generosity) conditional on whether the individual is a globalization winner or loser. In contrast to theoretical expectations, our results indicate that actual economic globalization does not affect people's perception in the manner expected by the compensation hypothesis. However, individuals display more positive attitudes toward globalization if welfare state generosity is proxied using government spending on active labor market programs.
\end{abstract}

$\mathrm{W}$ ith the recent global financial crisis, the failure of numerous banks and states on the brink of economic collapse, the financial interlinkages, which have been considered for so many years as a means to achieve prosperity, were increasingly questioned. Furthermore, the "real" and long-term consequences of such virtual speculative disaster on national economies still have not been fully understood.

However, not only financial markets without supervision are in question but globalization as a whole. Headlines were full of gloomy messages depicting the specter of economic nationalism rising again with protectionism cited as an option for governments to preserve jobs and because workers are demanding help (cf. The Economist 2009). These developments seem to be in line with Rodrik $(1997,6)$ predicting that: "the domestic consensus in favor of open markets will ultimately erode to a point where a generalized resurgence of protectionism becomes a serious possibility." Recent developments make new insights within research on the globalizationwelfare nexus ever more important and topical.

The scholarly literature on the relationship between globalization and increased government spending as a means to compensate losers is abundant (Rodrik 1998; Burgoon 2001; Pierson 2001; Genschel 2004; Hays, Ehrlich and Peinhardt 2005; Down 2007; Walter 2010). However, conclusive evidence has yet to be found on the causal link between increasing trade levels and increasing government spending on both micro and macro levels of analysis (Hays 2009). Whereas early studies mostly focused on finding a robust relationship between country-level globalization and government spending, the more recent literature has turned to individuals' perception of globalization (Hainmueller and Hiscox 2006). Although standard trade models give some guidance as to which individuals should embrace more or less protectionism, the results of recent empirical studies are less than conclusive (Hays, Ehrlich and Peinhardt 2005; Mayda and Rodrik 2005; Hays 2009).

* Lena Schaffer Postdoctoral Researcher, ETH Zürich, Center for Comparative and International Studies (CIS) (schaffer@ir.gess.ethz.ch); Gabriele Spilker, Assistant Professor of International Politics, University of Salzburg (gabriele.spilker@sbg.ac.at). 
Hence, this article intends to add to both strands of literature-macro and micro level—by analyzing the conditional effect of country-level economic globalization and welfare spending on individuals' perception of globalization. Following the idea of the compensation hypothesis, governments should compensate losers of globalization to mediate the perceived threat from globalization. Implicit in this logic is the idea that increasing levels of globalization may cause negative sentiments against globalization as the world becomes less predictable and secure (e.g., globalization may result in jobs being moved). Governments can increase support for globalization by providing a safety net in the form of a more generous welfare state. In this paper, we offer an additional test of this idea by linking country-level economic globalization and welfare spending to individual perceptions of globalization. We thus make the effect of actual economic globalization/welfare generosity conditional on those individual-level characteristics highlighted by international trade theory. We hypothesize that globalization winners (more educated people and capital owners) react differently to higher levels of globalization/ welfare spending compared with globalization losers (less educated people and people working in professions that are likely to be threatened by globalization such as manual workers). Thus, the aim of this article is to understand how country-level economic globalization as well as country-level compensation feed back to individual perceptions and whether these perceptions are contingent on given individual characteristics such as income, education and employment.

This paper therefore makes several contributions: first, as stated above, we explicitly focus on the conditional effects implicit in the assumptions of the compensation hypothesis by testing the macro-micro links. Substantively, we assess whether (a) people in countries that are more open to economic globalization do in fact perceive a higher external risk (Rodrik 1998); and (b) we test whether citizens whose governments have indeed provided compensation in the form of a bigger welfare state perceive economic globalization as less threatening. On the basis of these context-conditional effects (level of actual economic globalization/compensation granted by the government), we then go on to evaluate whether these individual perceptions of globalization are conditional on the individuals being winners or losers of globalization. That means, e.g., to assess whether losers of globalization indeed feel more threatened by globalization than winners. Importantly, both of the macro-micro links are not a test of the compensation hypothesis as a whole, but rather a test of implications of the causal claims made within this framework. From the decision to model the links between the macro and the micro level follows our second contribution. To arrive at more thorough tests of these causal claims, we improve on standard literature in this field by employing a hierarchical estimation strategy to adequately model influences from different levels of analysis (Steenbergen and Jones 2002; Gelman and Hill 2007). Third, we empirically focus our analysis on a survey question that is directly aiming at the effects of economic globalization, whereas most of the survey questions employed by the literature have so far relied on questions regarding governments' use of protectionism, which, however, is not an option specified within the compensation hypothesis. ${ }^{1}$ Furthermore, our survey question specifies explicitly that we are interested in the implications of globalization for the self. Recent scholarly contributions have increasingly discussed whether individuals do form their preferences owing to (material) self-interest or with a sociotropic view on, e.g., how the

\footnotetext{
${ }^{1}$ In reality, governments can react in many different ways to protect their citizens from globalization. They could subsidize the national economy, they could increase tariffs or, which is the mechanism proposed by the compensation hypothesis, provide a strong social safety net. In our view, lowering tariffs as implied by asking for individuals' perception on trade liberalization therefore does not capture the logic of the compensation hypothesis. This is why we consider it important to focus on a question that asks for individual perceptions on globalization instead.
} 
nation is faring under globalization (Sears and Funk 1990; Fordham 2008; Mansfield and Mutz 2009; Fordham and Kleinberg 2012; Bechtel, Hainmueller and Margalit 2014).

Our results show that increased actual globalization either does not affect individual-level attitudes or makes individuals living in more open countries more inclined to view globalization as favorable. Furthermore — and in line with standard trade theory—we find that capital owners, highly educated individuals, as well as people working in professions that should profit from globalization, tend to have a more positive attitude toward trade. For the second macro-micro link assessing whether governments that provided compensation were successful in making their citizens less anxious about globalization, results were mixed depending on the respective measure of welfare state generosity. For active labor market (ALM) spending we find a strong positive effect.

Overall, our results provide some support for the conditional effects implicit in the compensation hypothesis and regarding standard trade theory. If we go one step further and test whether the perception of globalization by those who are losing (winning) from trade is indeed contingent on the actual level of economic globalization and welfare state generosity in the respective country, we get only mixed support for our hypothesis that actual economic globalization levels reinforces globalization losers and winners in their attitude toward economic openness. As postulated by theory, a high level of actual economic globalization reduces the likelihood that a trade loser sees globalization as something positive in certain specifications (when classifying winners and losers according to skill level and factor endowment) and reinforces the more positive attitudes of trade winners to become even more positive (when classifying winners and losers according to factor endowment and profession). Concerning the interaction between compensation and being a winner or a loser of globalization, our findings show that for both winners and losers living in a country with a strong social safety net increases their likelihood of seeing globalization as something positive.

\section{THE COMPENSATION HYPOTHESIS}

The compensation hypothesis focuses on the influence of globalization on the demand side of the political market. It is argued that governments increase their public spending in order to compensate their citizens for the perceived risks owing to globalization. Figure 1 depicts the chain of argumentation underlying most of the articles dealing with the compensation hypothesis (Boix 2004; Scheve and Slaughter 2004; Hays, Ehrlich and Peinhardt 2005; Baker 2008; Walter 2010). In this representation of the compensation hypothesis, increased levels of globalization on the national level are supposed to increase either economic volatility or induce structural adjustments to the economy. Both of these might trigger economic insecurity and fears of job losses for individuals who are not equipped with either the comparatively advantaged factors of production or work in disadvantaged sectors of the economy (depending on which standard trade theory is considered). These economic insecurities are then assumed to translate into preferences for social protection and compensation. These preferences are aggregated and carried over to the government through parties, interest groups, elections, etc., and manifest themselves in a more compensatory welfare state policy. ${ }^{2}$

The conjecture that there is a link between increased globalization and higher social spending has been tested as well as contested by various authors. A positive relationship between openness and government size is supported by the findings of Hicks and Swank (1992), Huber,

\footnotetext{
${ }^{2}$ For a comprehensive account of the theoretical micro-relationships the compensation hypothesis consists of, see Walter (2010).
} 


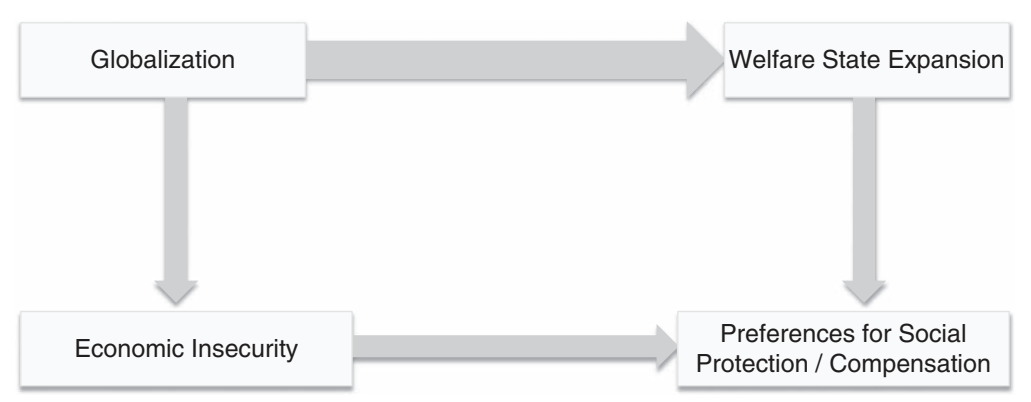

Fig. 1. Diagrammatic representation of compensation hypothesis

Ragin and Stephens (1993), Rodrik (1998), and more recently scholars such as Meinhard and Potrafke (2012). Potrafke (2009) further shows whether globalization's effect on the welfare state is contingent on partisan politics. He finds that when globalization is proceeding rapidly, there is a partisan effect to the extent that leftist governments increase social expenditures.

In contrast, Iversen and Cusack (2000) argue that the expansion of the welfare state in developed democracies is not because of globalization or external risk, but rather due to internal risk factors. They find that the observed growth in government consumption and transfers can be explained as a function of the severity of employment losses in traditional sectors, i.e., internal risk, and not globalization or external risk. Coming from a different direction but also sceptical about the causal link between globalization and welfare spending, Down (2007) tests the economic volatility link and finds that trade exposure does not affect economic volatility in a systematic manner such that it could have caused significant movements in government welfare spending.

However, in the scholarly literature on the globalization-welfare nexus, debate has not only centered on alternative explanations for welfare state expansion. Taking Garrett and Mitchell's (2001) article, in which the authors do not find support for the compensation hypothesis, as an example, Plümper, Tröger and Manow (2005) and Kittel and Winner (2005) show that the results are sensitive to econometric model specifications. Their re-analyses both arrive at similar conclusions as the ones drawn by Iversen and Cusack (2000); namely that the internal economic environment is much more relevant to welfare spending as opposed to globalization forces or the partisan composition of the government. As a consequence not only of methodological criticism inherent in many of these studies but mostly because they are solely testing a macrolevel relationship, a point excellently shown by Hays' (2009) re-analysis of Iversen and Cusack (2000), one should be careful when drawing inferences from these studies.

\section{Compensation Hypothesis at the Micro Level}

The assumptions underlying the compensation hypothesis have been largely taken for granted in research looking at the macro level of the relationship. It is therefore speculative when Rodrik observes that "[s]ocieties seem to demand (and receive) an expanded government role as the price for accepting larger doses of external risk" (Rodrik 1998, 998, emphasis added). In recent years, however, a vivid research area has evolved taking a closer look at the micro-level foundations of the relationship between globalization and the welfare state (Scheve and Slaughter 2001; Scheve and Slaughter 2004; Hays, Ehrlich and Peinhardt 2005; Mayda and Rodrik 2005; Hays 2009; Mansfield and Mutz 2009; Rehm 2009; Walter 2010). These studies have tested different parts of the compensation hypothesis including evidence from lower levels than the nation state, and these serve as the starting point for our own research. 
Scheve and Slaughter (2004) are among the few to explicitly test the relationship whereby globalization causes increased economic insecurity to workers. Although they emphasize a different notion of globalization by using foreign direct investment (FDI) instead of trade, their panel study shows that FDI has one of the largest substantive effects in accounting for the within-individual variation in economic insecurity as well as between industries. Walter (2010) arrives at the same conclusion when using FDI to test the link between globalization and economic insecurity in Switzerland. She further finds support for the causal micro links going from increased globalization to compensation in the Swiss context.

The studies that are closest to our own research are the ones by Mayda and Rodrik (2005) and Hays (2009). Mayda and Rodrik (2005) seek to explain individuals' attitude toward trade by using economic as well as non-economic individual-level factors. They find that individuals in sectors with a comparative disadvantage have a negative attitude toward trade, whereas individuals with better economic status or those in non-traded sectors are pro-trade.

In a similar vein, Hays (2009) tests the embedded liberalism claim. He first shows that individuals who work in the tradable industry and particularly in the import-competing industry, as well as the unemployed or individuals with low education levels, are opposed to free trade. Then, in a second step, he shows that these negative attitudes against trade can be mitigated through compensation in the form of unemployment programs and also government programs.

We add to the existing literature in three ways. First, and in contrast to all of the above microlevel studies, which use survey questions referring to free trade or protectionism as their indicators, we try to directly assess survey respondents' views on globalization. This is important as we think it is globalization as a concept that lies at the heart of arguments concerning the compensation hypothesis and not trade protection. Second, we analyze the reaction of individuals toward globalization conditional on the actual level of economic globalization in their country and the actual level of compensation granted. The motivation for focusing on these context-conditional effects comes from the observation that only a closer look reveals some open theoretical questions concerning the —at first sight—intuitively plausible link between globalization and welfare state spending. Do citizens actually perceive economic globalization; do they see it as a threat and associate job insecurity with it? Which actions do citizens really take to improve their situation and why would they not demand protectionism as a direct policy reaction to globalization but demand state-sponsored redistribution instead (Baker 2008)? This last point is especially important, as understanding the implications of certain policies on personal livelihood seems to exceed most citizens' understanding of politics as research on the general public's knowledge has shown (Carpini and Keeter 1993; Carpini and Keeter 1997; Galston 2001). Third, and more importantly, we also take into account individual characteristics that are supposed to impact differently on an individual's preference toward

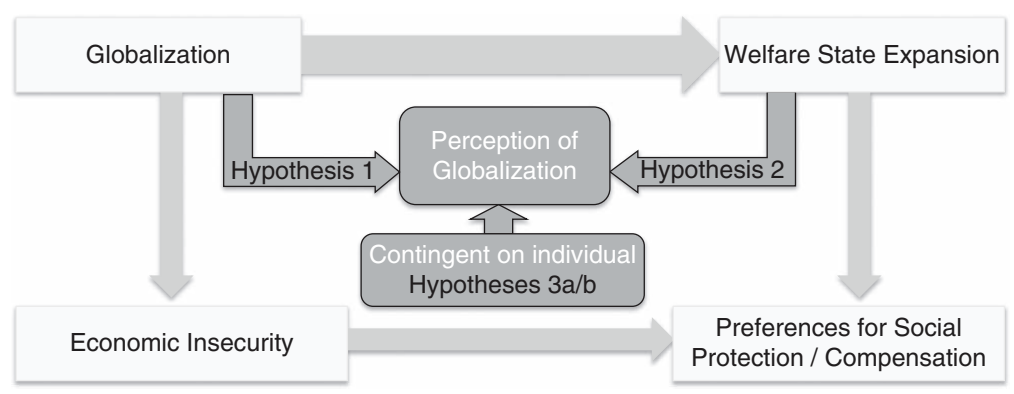

Fig. 2. Diagrammatic representation of our argument 
globalization, depending on the given context (actual economic globalization/generosity of the welfare state).

Figure 2 depicts again the chain of argumentation underlying most of the articles dealing with the compensation hypothesis (outside arrows), as well as the arguments tested in this article (inside arrows), where Hypotheses 1 and 2 look at the context-conditionality of globalization preferences. Hypotheses $3 \mathrm{a}$ and $3 \mathrm{~b}$ then interact the given context (actual economic globalization/generosity of the welfare state) with individual characteristics to determine an individual's globalization preference.

\section{CONTEXT-CONDITIONALITY OF GLOBALIZATION PREFERENCES}

\section{Actual Economic Globalization and the Attitude Toward Globalization}

Our research starts by clarifying if people actually perceive economic globalization as threatening. For the compensation hypothesis to hold, people need to perceive globalization as negative; otherwise, they would not demand compensation because of globalization and the whole argumentation underlying this hypothesis crumbles. Hence, individuals' attitudes toward globalization should be contingent on the actual level of economic globalization. Controlling for individual-level factors, we test whether individual attitudes toward globalization differ with various measures of actual economic globalization at the country level (e.g., trade openness). We expect that if the compensation hypothesis holds, people in more open economies should exhibit a relatively more negative attitude toward globalization. This awareness of globalization should happen even before people mentally make the connection from increased globalization to increased economic uncertainty or to increased attitudes toward redistribution (Rehm 2009; Walter 2010). The rationale behind this is that if people do not perceive more globalization as negative, why should they react to globalization by demanding compensation at all? We therefore stipulate that:

HYPOTHESIS 1: The more economically open a country is, the more negative the attitude of its citizens toward globalization.

\section{Compensation and the Attitude Toward Globalization (Embedded Liberalism)}

The second relationship in the compensation hypothesis assumes people aggregate their preferences for compensation via elections (cf. Walter 2010) or other forms of aggregation; and then governments react to these demands for greater shelter from globalization. However, it is not clear from theory why certain kinds of compensation are demanded and not others. ${ }^{3}$ Furthermore, the mechanism by which people actually aggregate their welfare state preferences-e.g., through elections, parties or interest groups - and how these are translated into policies is still an ambiguous and understudied area in the context of the compensation hypothesis. ${ }^{4}$

However, if we assume the hypothesis holds, it would only be rational for governments to compensate citizens if compensation really is perceived by citizens as a cushion against globalization. It follows that people indeed need to make the connection between welfare spending and globalization, or why should a government then bother to compensate? This implication of the compensation hypothesis assumes that people actually link an increase in compensation granted by the government to a better individual position vis-à-vis globalization.

\footnotetext{
${ }^{3}$ For an empirical treatment of this subject, see Hays (2009) and Baker (2008).

4 A notable recent effort to look into more detail with respect to welfare state preferences and vote choice is Walter's (2010) study.
} 
Consequently, they should react in a manner proposed by the embedded liberalism argument (Ruggie 1982; Hays 2009) and should accordingly acknowledge more compensation with a more positive attitude toward globalization. Hence, we test whether instruments of welfare spending matter for citizens as far as globalization fears are concerned. Hays, Ehrlich and Peinhardt (2005) and Hays (2009) explicitly test this claim in their work and find that "government programs designed to protect individuals harmed by imports reduce opposition to free trade" (Hays, Ehrlich and Peinhardt 2005, 473). This result is robust in their micro-level model as well as their separate macro-level specification.

In our hierarchical framework, which accounts for the context in which people are embedded, we investigate whether individual-level attitudes toward globalization vary with measures of government spending at the country level. As we believe that granting benefits to losers of globalization does help people to view globalization as a necessary and good development and in line with the claims of embedded liberalism, we hypothesize that:

HYPOTHESIS 2 (EMBEDDED LIBERALISM): The more compensation the government grants, the more positive are citizens' attitude toward globalization.

\section{Individual Characteristics and the Attitude Toward Globalization}

Having looked at how different national contexts impact on an individual's globalization preference and thereby testing the macro-micro implications underlying the compensation hypothesis, we now turn to the question whether individuals' attitude might differ depending on their personal characteristics, be they economic, social or demographic.

We therefore rely on standard trade theory as well as other theoretically relevant concepts to predict individual attitudes toward globalization. ${ }^{5}$ In the classical Stolper-Samuelson theorem (as an implication of the Heckscher-Ohlin (H-O) model), free trade benefits individuals owning the relatively abundant factor (in our set of developed countries these are the owners of capital or the owners of labor skills (Oatley 2010)), and hence these individuals tend to favor globalization, whereas unskilled and low-skilled labor as the owners of disadvantaged factors see a decline in their real incomes. In contrast to the $\mathrm{H}-\mathrm{O}$ model, the specific factors model, or the Ricardo-Viner $(\mathrm{R}-\mathrm{V})$ framework, predicts that sectors serve as the conflicting lines concerning preferences toward free trade. Accordingly, individuals who receive their income from sectors gaining from globalization, will be in favor of trade openness, whereas those individuals who receive their income from sectors that are comparatively disadvantaged will oppose trade openness.

With regard to empirical support for these two standard trade theories, there is still no consensus as to whether the H-O model or the R-V model fits the stylized facts best. Whereas Hays, Ehrlich and Peinhardt's (2005) results show that individuals employed in import-competing industries are the strongest opponents of trade, Scheve and Slaughter (2001) rather find support for the factorendowment model. Using individual-level survey data to explain trade policy preferences, Scheve and Slaughter (2001) find that factor-type eclipses industry of employment in terms of explaining individual support for trade barriers. That individual trade preferences interact with country characteristics as predicted by the $\mathrm{H}-\mathrm{O}$ model is one of the key findings and a very robust result in Mayda and Rodrik's (2005) study. However, they also find some, albeit less support for the R-V model. Looking at redistributional preferences rather than trade preferences, Rehm (2009) also concludes that it is an individual's occupation and not the industry of employment that shapes redistributional demand.

\footnotetext{
5 An assumption made here is that individuals do care about personal well-being before national well-being and are motivated by material self-interest.
} 
Independent of whether one believes the $\mathrm{H}-\mathrm{O}$ or the $\mathrm{R}-\mathrm{V}$ model to be correct, it seems warranted to take into account that those individuals who are winning from trade- be it because they possess the abundant factor in this economy or because they work in the corresponding sector-should perceive globalization differently from those individuals who are losing from trade.

Actual economic globalization and individual characteristics. We thus argue that actual economic openness should reinforce both winners and losers from trade in their perception of globalization. More precisely, individuals who are supposed to benefit from trade should be reinforced in their positive perception on globalization. As living in an open economy should make a globalization winner even better off relative to a globalization loser, the positive attitude toward globalization should be more pronounced in a more open economy. In contrast, those individuals who are losing out from globalization should evaluate it even worse when exposed to higher levels of actual economic globalization. We expect this to be the case because globalization losers living in more open economies should be under an even higher pressure by globalization than if they were living in less globalized countries. Consequently, we adapt Hypothesis 1 to this argument and hypothesize that individuals' perception on globalization should be contingent on whether they are winning or losing from trade:

HYPOTHESIS 3A: Citizens' attitude toward globalization should vary with the level of actual economic globalization contingent on whether an individual loses or wins from trade.

Welfare state generosity and individual characteristics. In a similar vein, individuals losing out from globalization and those winning from globalization should differ in their attitude toward globalization, given the level of compensation their governments grant. However, in this case, the logic should not be of a reinforcing, but rather of a compensating nature. Recalling the theoretical underpinnings of the compensation hypothesis, it is argued that (potential) losers of globalization will demand compensatory policies from their government to shield them from the vagaries of globalization. Consequently, following the argument presented in this paper, that means given the context of the national level of welfare state generosity, we expect differences in an individual's attitude toward globalization depending on whether he or she wins or loses from globalization. We thus expect a respondent's reaction being conditional on the context (Hypothesis 2) and on their individual characteristics.

As winners of globalization should embrace globalization simply because they are winners, they should be indifferent to living in a country with high levels of welfare generosity. For these individuals the event of losing their job because of globalization is highly unlikely, as is the event of having to rely on the government-sponsored social safety net. Hence, we do not expect globalization winners' preferences to differ given the national welfare context. In contrast, the actual level of the government-sponsored safety net should make a real difference for those individuals who feel threatened by globalization. According to the embedded liberalism claim, those individuals losing out have to be shielded from globalization to allow governments a further opening of markets that would benefit society as a whole. However, for globalization losers living in countries that do not offer sufficient compensation, such respondents are assumed to display a negative opinion on globalization. This implies that the level of welfare generosity should only make a difference for those individuals who feel threatened by globalization. In this case, more generous government-sponsored safety nets should make these individuals more prone to embrace globalization, whereas lower levels of government-sponsored 
Theoretical expectations for $\mathrm{H} 3 \mathrm{a}$ and $\mathrm{H} 3 \mathrm{~b}$ Agreeing that globalization is a good thing for oneself
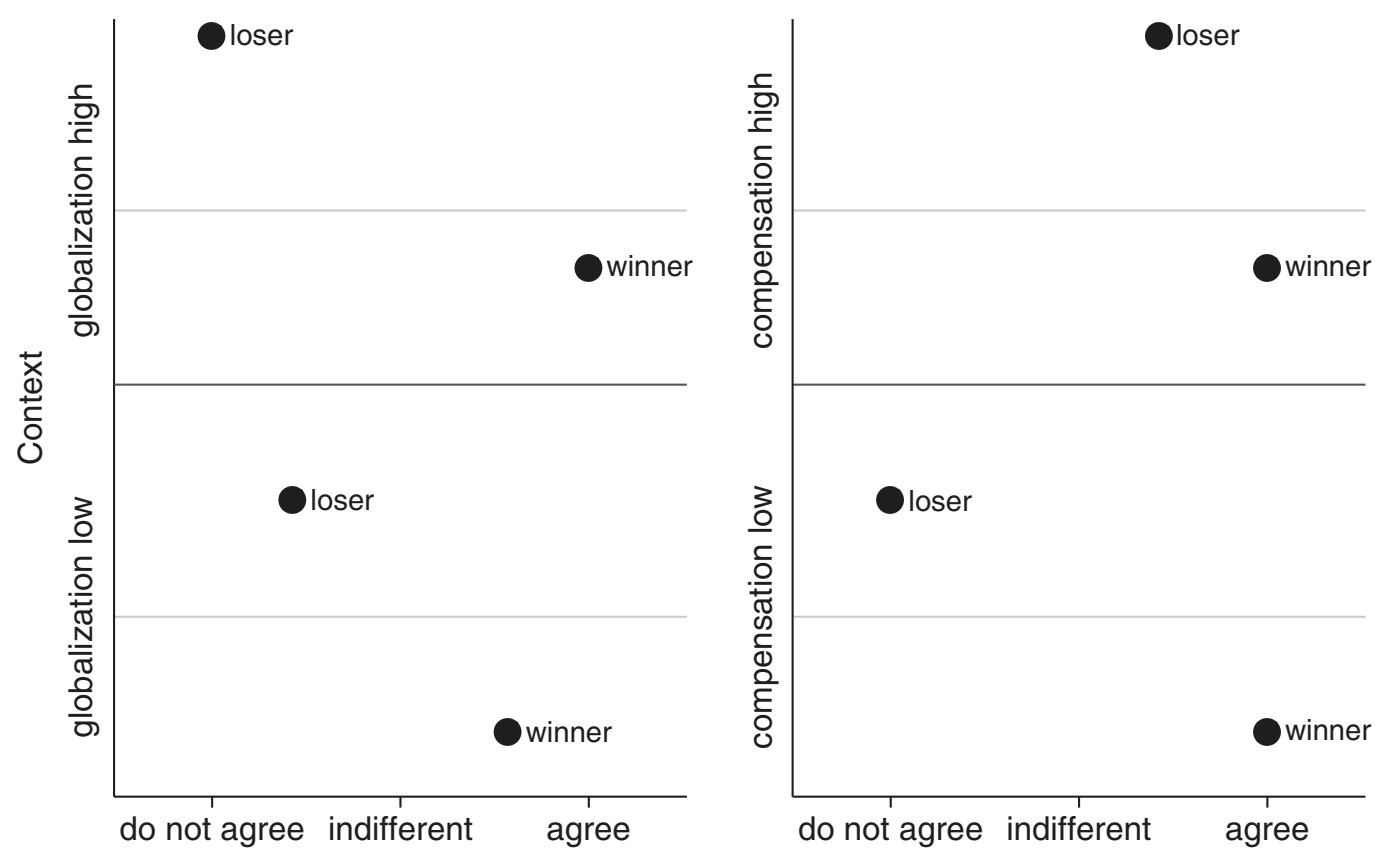

Fig. 3. Theoretical expectations for Hypotheses $3 a$ and $3 b$

safety nets should reinforce them in their negative attitude toward globalization. We thus stipulate that:

HYPOTHESIS 3B: Citizens' attitude toward globalization should vary with the generosity of the welfare state contingent on whether an individual loses or wins from trade.

In summary, Figure 3 graphs our theoretical expectations for the different country contexts (actual level of economic globalization/compensation) and individual characteristics (globalization winner/loser) in Hypotheses $3 \mathrm{a}$ and $3 \mathrm{~b}$.

The following section introduces the hierarchical framework used to test our hypotheses, describes our data set in detail and provides our results.

\section{EMPIRICAL ANALYSIS}

As discussed in the theoretical section, the aim of this paper is to test the conditional effect of actual economic globalization/compensation on individuals' perception of globalization. Hence, we are necessarily dealing with a phenomenon that extends over two levels of analysis: the macro (country) level and the micro (individual) level. Therefore, we rely on a hierarchical model framework. ${ }^{6}$ More specifically, we use a random-intercept logistic model to test Hypotheses 1 and 2 and a random-coefficient logistic model to evaluate Hypotheses $3 \mathrm{a}$ and $3 \mathrm{~b}^{7}$

\footnotetext{
${ }^{6}$ Using analysis of variance to decompose the variance in globalization perceptions indicates that there is indeed sufficient variation across our two levels of analysis. Results are available upon request.

7 The data we use were collected as multi-level data (individuals within different countries). Multi-level modeling offers a direct way to incorporate independent variables that vary both at the individual as well as at the country level without avoiding the problem of over-fitting (Gelman and Hill 2007). In addition, multi-level modeling allows to incorporate both predictors at the country level and correct for differences between the
} 
The random-intercept logistic model accounts for the fact that observations for individuals from the same country are not independent of each other (Rabe-Hesketh and Skrondal 2009). The model can be written as:

$$
\begin{aligned}
& \operatorname{logit}\left\{\operatorname{Pr}\left(y_{i j}=1 \mid x_{i j}, \zeta_{j}\right)\right\}=\beta_{0}+\beta_{1} x_{i j}+\beta_{2} x_{j}+\zeta_{j} \\
& \text { with } \quad \zeta_{j} \sim N(0, \psi) \\
& \text { and } \quad y_{i j} \sim \operatorname{binomial}\left(1, \pi_{i j}\right) \\
& \text { where } \quad \pi_{i j} \equiv \operatorname{Pr}\left(y_{i j}=1 \mid x_{i j}, \zeta_{j}\right) .
\end{aligned}
$$

The dependent variable $y_{i j}$ stands for individual $i$ of country $j$ 's attitude toward globalization, which is a binary variable. Next to a set of covariates, which can either vary at the individual $\left(x_{i j}\right)$ or the country level $\left(x_{j}\right)$, the model includes a country-specific intercept $\zeta_{j}$, which accounts for unobserved heterogeneity at the country level (Rabe-Hesketh and Skrondal 2009). This country-specific random intercept is modeled as following a normal distribution.

The random-coefficient logistic model, in contrast to the random-intercept model, allows the estimated coefficients of the covariates to also vary between countries. More importantly, it is possible to let the estimated coefficients of the individual-level covariates vary with the level of economic globalization or the level of compensation observed at the country level. This procedure therefore permits us to test whether, e.g., individuals who lose from globalization perceive it less favorably in countries that are more globalized compared with globalization losers who live in less globalized countries.

\section{Variables and Operationalization}

Our individual-level data are taken from the Eurobarometer 2004 spring survey (ZA4056), which includes respondents from the European Union's 15 oldest member countries. The Eurobarometer is a European-wide survey consisting of around 1000 interviews per member state of the European Union (Eurobarometer 2004). ${ }^{8}$ We have chosen this particular Eurobarometer survey because of various reasons. First, the Eurobarometer is the only crossnational survey that we know of which poses questions directly about individuals' perception of globalization and not on globalization-related issues such as protectionism as is the case for the International Social Survey Programme (Mayda and Rodrik 2005). ${ }^{9}$ Second, the question about globalization gives a clear definition of what globalization is supposed to mean. Therefore, all respondents should in principle answer this question with a conception of economic globalization in mind. Furthermore, by explicitly asking for the implications of globalization on the self,

(F'note continued)

different countries that cannot be measured by these predictors (Gelman and Hill 2007). In the words of Gelman and Hill "The multilevel model provides a coherent model that simultaneously incorporates both individual- and group-level models" (Gelman and Hill 2007, 8).

${ }^{8}$ The only exceptions are Luxembourg with 600 interviews, the United Kingdom with 1000 interviews for Great Britain and 300 for Northern Ireland and Germany with 1000 interviews in the western as well as in the eastern part.

9 Former studies dealing with individuals' perception on globalization-related issues often rely on the American National Election Survey (Scheve and Slaughter 2001; Hainmueller and Hiscox 2006). As we need survey data encompassing different countries to ensure variation in the level of economic globalization to test our argument, we cannot rely on the NES data. 
sociotropic concerns, i.e., forming one's trade preference according to how the country is faring under globalization can be somewhat minimized.

These many advantages of the survey come along with one disadvantage: we cannot directly allocate the professions of the interviewees to exporting or import-competing sectors. This implies that we cannot directly test the implications of the R-V trade model following the standard procedure in the literature (Hays 2009; Mansfield and Mutz 2009). Instead, we need to rely on information on both the profession of the interviewees as well as their education levels to construct a variable indicating whether their occupation is likely to be threatened by globalization. ${ }^{10}$

To measure our dependent variable, citizens' attitude toward globalization, we use the following question:

You may have heard of globalisation, that is the general opening-up of all economies, which leads to the creation of a world-wide market. [...], could you please tell me if you tend to agree or if you tend to disagree? Overall, globalisation is a good thing for ME: Tend to agree; Tend to disagree; Don't know.

We coded the 5260 respondents, who answered that they agree with the statement that globalization is good for themselves, as 1 and the 6780 respondents, who did not agree with the statement, as 0 . Persons answering "I do not know" were coded as missing values. ${ }^{11}$ Table 1 shows how many individuals per country agree that globalization is good for themselves and how many do not agree with this statement. In the United Kingdom, Ireland, the Netherlands, Finland, Sweden and Denmark a majority believes that globalization is good for themselves, whereas most people in Germany, France, Greece, Italy, Belgium, Spain and Austria perceive globalization as negative for themselves. Altogether, a majority of the respondents consider globalization not to be a good thing for them personally.

To measure actual economic globalization, we incorporate trade openness (the log of exports + imports divided by a country's gross domestic product (GDP)) as a country-level predictor in our models (Heston, Summers and Aten 2006). However, as is common in the literature, we use further indicators of economic globalization in order to check the robustness of our results (see section on robustness checks) (Garrett and Mitchell 2001; Brady, Beckfield and Seeleib-Kaiser 2005; Dreher, Sturm and Ursprung 2008). As different measures pertaining to the generosity of the welfare system exist (Garrett and Mitchell 2001; Hays 2009), we rely on two different proxies. First, we use government spending on ALM programs as a percentage of government spending; and second, we rely on government spending related to unemployment as a percentage of total government spending. Both variables are taken from the OECD Social Expenditure Database. As the Eurobarometer survey took place at the beginning of 2004, we use a five-year average of all the independent variables that vary at the country level to ensure that they were measured well before the date of our survey. This is of particular importance for our welfare state measures to control for the possibility that citizens already feel compensated by their government and therefore feel cushioned against globalization.

\footnotetext{
${ }^{10}$ Although it would be preferable to be able to allocate the respondents to exporting or import-competing sectors, most literature shows that skill-level and capital ownership seem to be more important factors in predicting individuals' attitudes toward trade (Scheve and Slaughter 2001; Scheve and Slaughter 2006; Rehm 2009). Or in the words of Scheve and Slaughter "The effects of skill trade exposure are large and precise; the effects of industry trade exposure are small and uncertain" (Scheve and Slaughter 2006, 239).

11 In all, 4176 answered "I do not know." To ensure that this does not affect our results, we coded for robustness checks the "I do not know" individuals once as positive and once as negative answers. The results for both kind of models are virtually the same. They are available upon request from the authors.
} 
TABLE 1 Descriptive Statistics of Dependent and Country Variables

\begin{tabular}{|c|c|c|c|c|c|c|}
\hline & $\begin{array}{l}\text { Globalization } \\
\text { Not Good for Me }\end{array}$ & $\begin{array}{l}\text { Globalization } \\
\text { Good for Me }\end{array}$ & Total & Trade & ALM & $\begin{array}{c}\text { Unemployment } \\
\text { Benefits }\end{array}$ \\
\hline Austria & 566 & 285 & 851 & 90.35 & 1.1 & 1.98 \\
\hline Belgium & 489 & 273 & 762 & 159.35 & 2.3 & 5.98 \\
\hline Denmark & 281 & 447 & 728 & 85.09 & 3.45 & 5.6 \\
\hline Finland & 373 & 408 & 781 & 70.22 & 1.85 & 4.4 \\
\hline France & 615 & 195 & 810 & 52.88 & 2.1 & 3.02 \\
\hline Germany & 1002 & 506 & 1508 & 65.24 & 2.55 & 3.38 \\
\hline Greece & 549 & 280 & 829 & 53.90 & 0.35 & 0.82 \\
\hline Ireland & 273 & 376 & 649 & 170.50 & 2.6 & 2.56 \\
\hline Italy & 479 & 305 & 784 & 52.80 & 1.3 & 0.84 \\
\hline Luxembourg & 272 & 214 & 486 & 270.44 & 0.6 & 1.42 \\
\hline The Netherlands & 343 & 433 & 776 & 124.64 & 3.25 & 2.98 \\
\hline Portugal & 357 & 337 & 694 & 69.99 & 1.3 & 1.7 \\
\hline Spain & 454 & 219 & 673 & 57.50 & 1.7 & 5.4 \\
\hline Sweden & 332 & 515 & 847 & 82.33 & 2.95 & 2.2 \\
\hline United Kingdom & 395 & 467 & 862 & 55.90 & 1.05 & 0.8 \\
\hline
\end{tabular}

$\mathrm{ALM}=$ active labor market.

Table 1 also lists the data for the three independent country-level variables. The data show that in many countries with low trade openness, such as France, Spain, Italy or Greece, a majority perceives globalization as negative, which runs counter to our expectation formulated in Hypothesis 1 . The response pattern in countries with high trade openness, however, is much more mixed: in some countries, such as Ireland and the Netherlands, high trade openness goes hand in hand with a positive feeling about globalization, whereas in other countries, such as Luxembourg and Belgium, a majority dislikes globalization. The descriptive statistics concerning the generosity of the welfare state shows even less of a clear-cut pattern between ALM and unemployment spending on the one hand and people's attitude toward globalization on the other.

On the individual level, the variables of interest are a respondent's skill level, whether she is a capital owner and whether professionally she wins or loses from globalization. Using all of the three variables in the same model would potentially overfit the data because it is highly unlikely that someone is very well educated, a capital owner but would professionally lose from globalization. Hence, we incorporate either a respondent's education or whether she is a globalization winner in our model, but not both variables at the same time. ${ }^{12}$ First, we measure the skill level of each individual by her education level. The Eurobarometer asks its interviewees how old they were when they finished their full-time education. This gives us a continuous measure of education, which is in line with other studies such as Scheve and Slaughter (2001). For those respondents who were still studying we use their current age instead. ${ }^{13}$

Second, we use dummies indicating the income quartile a respondent belongs to in order to proxy whether she is a capital owner (Hays 2009).

Third, we rely on specific combinations between a respondent's profession and her education to construct a variable indicating whether someone's profession is likely threatened by globalization as predicted by the sector-specific trade model. Those people who are unemployed

\footnotetext{
12 However, results do not change when we enter all three variables in the same model.

13 The maximum age of education is 40 years. However, a few respondents in their 50s and 60s answered that they were still studying. As it is very unlikely that they have been studying their entire adult life, we decided to set their age of education to the maximum of 40 years.
} 
TABLE 2 Descriptive Statistics

\begin{tabular}{|c|c|c|c|c|c|}
\hline & Mean & SD & Minimum & Maximum & $N$ \\
\hline Winner & 0.73 & 0.45 & 0 & 1 & 16,216 \\
\hline 2nd income quartile & 0.27 & 0.44 & 0 & 1 & 11,044 \\
\hline 3rd income quartile & 0.23 & 0.42 & 0 & 1 & 11,044 \\
\hline 4th income quartile & 0.25 & 0.44 & 0 & 1 & 11,044 \\
\hline Education & 18.30 & 4.82 & 6 & 40 & 16,216 \\
\hline Gender & 0.52 & 0.50 & 0 & 1 & 16,216 \\
\hline Age & 45.33 & 18.34 & 15 & 98 & 16,216 \\
\hline Left & 0.33 & 0.47 & 0 & 1 & 13,199 \\
\hline Right & 0.26 & 0.44 & 0 & 1 & 13,199 \\
\hline
\end{tabular}

are assigned to be trade losers, independent of their education level. This is also true for farmers, fishermen and unskilled manual works who should all lose from increased globalization. Shop owners and craftsmen who have an education level of $<20$ years are also assigned to be trade losers. Similarly, less educated ( $<20$ years) respondents working in employed positions are also thought of as globalization losers.

In contrast, skilled manual workers, employed and self-employed professionals, business proprietors, supervisors, managers and people working in a service job should all win from trade, independent of their education. This should also be the case for highly educated middle management, owners of a shop, craftsmen and highly educated people working in employed positions. ${ }^{14}$ A little bit more controversial are those individuals who are either retired or students. As retired people in most of our countries obtain their income from a secure source that is not affected by globalization, we decided to allocate the retired as globalization winners. Similarly, students belong to the part of society that is highly educated, which should allow them to find highly qualified jobs not threatened by globalization. However, we check the robustness of our globalization-winner measure by allocating either students or retired or both also to the globalization losers.

Moreover, we include further variables that are commonly controlled for in studies of individuals' perceptions of globalization-related issues (Scheve and Slaughter 2001; Mayda and Rodrik 2005; Hainmueller and Hiscox 2006). First, we include a respondent's gender and age in our regression model. Second, we include dummy variables capturing individuals' political attitudes (Cusack, Iversen and Rehm 2005; Rehm 2009). The variable left takes on the value 1 for those individuals that have placed themselves on the left when asked for a self-placement on a left-right continuum. In contrast, the variable right characterizes those citizens who have placed themselves on the right of this continuum. The baseline category for both dummies is composed of those citizens who placed themselves in the center of this left-right continuum.

Table 2 shows the descriptive statistics for all of our variables.

\section{RESULTS}

Table 3 presents the results of the random-intercept logistic model testing Hypotheses 1 and 3 . The inclusion of the random effect seems important as it helps to capture significant unobserved heterogeneity at the country level. In none of the models is an increase in economic

\footnotetext{
${ }^{14}$ For those individuals who look after the household and are therefore not working, we use the profession of the head of the household to assign the person as either a trade winner or loser.
} 
TABLE 3 Random-Intercept Logistic Model

\begin{tabular}{lcccc}
\hline & $(1)$ & $(2)$ & $(3)$ & $(4)$ \\
\hline In trade openness & $0.36(0.236)$ & $0.38(0.238)$ & $0.44(0.258)^{*}$ & $0.46(0.265)^{*}$ \\
ALM & $0.22(0.123)^{*}$ & $0.25(0.124)^{* *}$ & & $-0.03(0.073)$ \\
Unemployment spending & & & $-0.02(0.075)$ \\
Education & $0.02(0.005)^{* * *}$ & & $0.02(0.005)^{* * *}$ & \\
Winner & & $0.23(0.058)^{* * *}$ & & $0.23(0.058)^{* * *}$ \\
2nd income quartile & $0.07(0.071)$ & $0.07(0.071)$ & $0.07(0.071)$ & $0.07(0.071)$ \\
3rd income quartile & $0.15(0.074)^{* *}$ & $0.15(0.074)^{* *}$ & $0.14(0.074)^{*}$ & $0.15(0.074)^{* *}$ \\
4th income quartile & $0.31(0.073)^{* * *}$ & $0.32(0.072)^{* * *}$ & $0.30(0.073)^{* * *}$ & $0.32(0.072)^{* * *}$ \\
Gender & $-0.16(0.049)^{* * *}$ & $-0.15(0.049)^{* * *}$ & $-0.16(0.049)^{* * *}$ & $-0.15(0.049)^{* * *}$ \\
Age & $-0.01(0.001)^{* * *}$ & $-0.01(0.001)^{* * *}$ & $-0.01(0.001)^{* * *}$ & $-0.01(0.001)^{* * *}$ \\
Left & $-0.22(0.058)^{* * *}$ & $-0.22(0.058)^{* * *}$ & $-0.22(0.058)^{* * *}$ & $-0.22(0.058)^{* * *}$ \\
Right & $0.21(0.061)^{* * *}$ & $0.21(0.061)^{* * *}$ & $0.21(0.061)^{* * *}$ & $0.21(0.061)^{* * *}$ \\
Constant & $-2.22(1.054)^{* *}$ & $-2.02(1.060)^{*}$ & $-2.06(1.151)^{*}$ & $-1.8(1.180)$ \\
$\sigma_{\zeta}$ & 0.42 & 0.43 & 0.46 & 0.48 \\
Observations & 7549 & 7549 & 7549 & 7549 \\
Number of countries & 15 & 15 & 15 & 15 \\
\hline
\end{tabular}

Standard errors in parentheses.

ALM = active labor market.

$* * * \mathrm{p}<0.01, * * \mathrm{p}<0.05, * \mathrm{p}<0.1$.

globalization associated with a respondent's view on globalization as predicted by Hypothesis 1 . In the models that rely on ALM spending as a proxy for welfare state generosity, trade openness is not significantly associated with individual-level perceptions at all. In the two models using unemployment spending, however, trade openness is significantly associated with individual trade perceptions, but counter to the specified relationship in Hypothesis 1. Individuals living in countries with higher trade openness seem to be more inclined toward a positive attitude with regard to globalization. Hence, the findings of all models shown in Table 3 do not lend support to Hypothesis 1 and therefore run counter to the implication underlying the compensation hypothesis that people living in more open economies perceive globalization as more negative.

Regarding our second hypothesis, which refers to the nexus between the generosity of the welfare state and individuals' perception of globalization, we receive mixed results depending on the measure used. As displayed in columns 1 and 2, if we rely on active labor market programs as percentage of government expenses, then ALMs significantly increase the likelihood of seeing globalization as beneficial. In contrast, expenses on unemployment programs (as displayed in columns 3 and 4) do not seem to alter people's perception of globalization at all. Thus, the results are partly in line with the second hypothesis implying that people living in more generous welfare states do indeed feel compensated by their government.

The results for the individual characteristics do not come as a surprise. Importantly, it does not make a difference whether we include a person's level of education (columns 1 and 3) or whether she works in a profession that is likely to benefit from globalization (columns 2 and 4). As predicted by theory, more educated people are more likely to assess globalization as something beneficial. In the same way, individuals whose jobs are likely to benefit from globalization also tend to consistently perceive it as positive, which is in line with the predictions of the sector-specific trade model. Furthermore, capital owners are significantly more likely to see globalization as a good thing for their country, lending support to the H-O trade model. 
With regard to a person's age, the results imply that older persons are significantly more likely to see globalization as something negative for themselves. Likewise, women seem to be more inclined to dislike globalization than men. This finding is in line with a growing literature on the gender gap with regard to globalization attitudes (Burgoon and Hiscox 2008). Finally, concerning political attitudes we see that individuals who place themselves politically on the left perceive globalization as negative, whereas individuals who place themselves on the right tend to think of globalization as something positive for themselves.

Both Hypotheses $3 \mathrm{a}$ and $3 \mathrm{~b}$ propose that the effect of actual economic globalization and actual compensation should vary depending on the individual being a globalization winner or loser. Table 4 shows the results if we additionally include interaction effects between openness and compensation on the one hand and the various variables that capture whether an individual can be thought of as a globalization winner on the other. Columns 1 and 2 in Table 4 show the interaction between the level of education to represent the winners of globalization and actual economic globalization or compensation, respectively. In Columns 3 and 4, we rely on capital ownership (belonging to the 4th income quartile) to represent globalization winners and in columns 5 and 6 we use the variable capturing whether an individual's profession should profit from globalization to represent globalization winners.

As the interpretation of the interaction effects is not straightforward within the context of a logistic multi-level regression model, we provide various graphs to visualize effect sizes. In Figures 4-9 we plot four different scenarios to assess the different possibilities covered by Hypotheses 3a and 3b: being a trade winner and living in a country with high trade openness (or high compensation), being a trade winner and living in a country with low trade openness (or low compensation), being a trade loser and living in a country with high trade openness (or high compensation) and being a trade loser and living in a country with low trade openness (or low compensation). For all these combinations we simulated predicted probabilities using a Bayesian multi-level model with flat priors. This approach allowed us to obtain a 90 percent confidence interval for the predicted probabilities and thus to capture the uncertainty underlying our estimates. More precisely, Figures 4-9 depict the 90 percent confidence interval of the predicted probability of seeing globalization as something positive depending on the four scenarios described above for a male individual with a center political attitude and age being kept at its median value (45 years). When simulating the predicted probabilities for the education interaction effects we do this for an individual who belongs to the 3rd income group. We then set education to its median value (18 years) for the simulation of the predicted probabilities for the income and professional winner interaction effects. Finally, we keep either ALM or trade openness at its median value when simulating the openness or ALM interactions, respectively.

The results displayed in Figure 4 lend some support to Hypothesis 3a: while for capital-owning individuals we see a positive reinforcing effect of actual openness, trade openness leads to a reduced likelihood of seeing globalization as something positive for individuals who are losing from globalization (not owning capital). This exactly mirrors our expectations given in Hypothesis 3a. However, the differences between the various scenarios are not very pronounced-only about a 1 percentage point difference (for winners: +1.2 , for losers: -0.7 difference between high and low openness).

The results change slightly when we consider education (Figure 5) instead of capital ownership (belonging to the 4th income quartile). Here, a high level of trade openness combined with a low level of education leads to a lower probability of seeing globalization as something positive than a low level of trade openness combined with a low level of education-about 7 percentage points lower. This supports the argument that for individuals who are losing from globalization (being not well educated) actual trade openness contributes to seeing globalization 


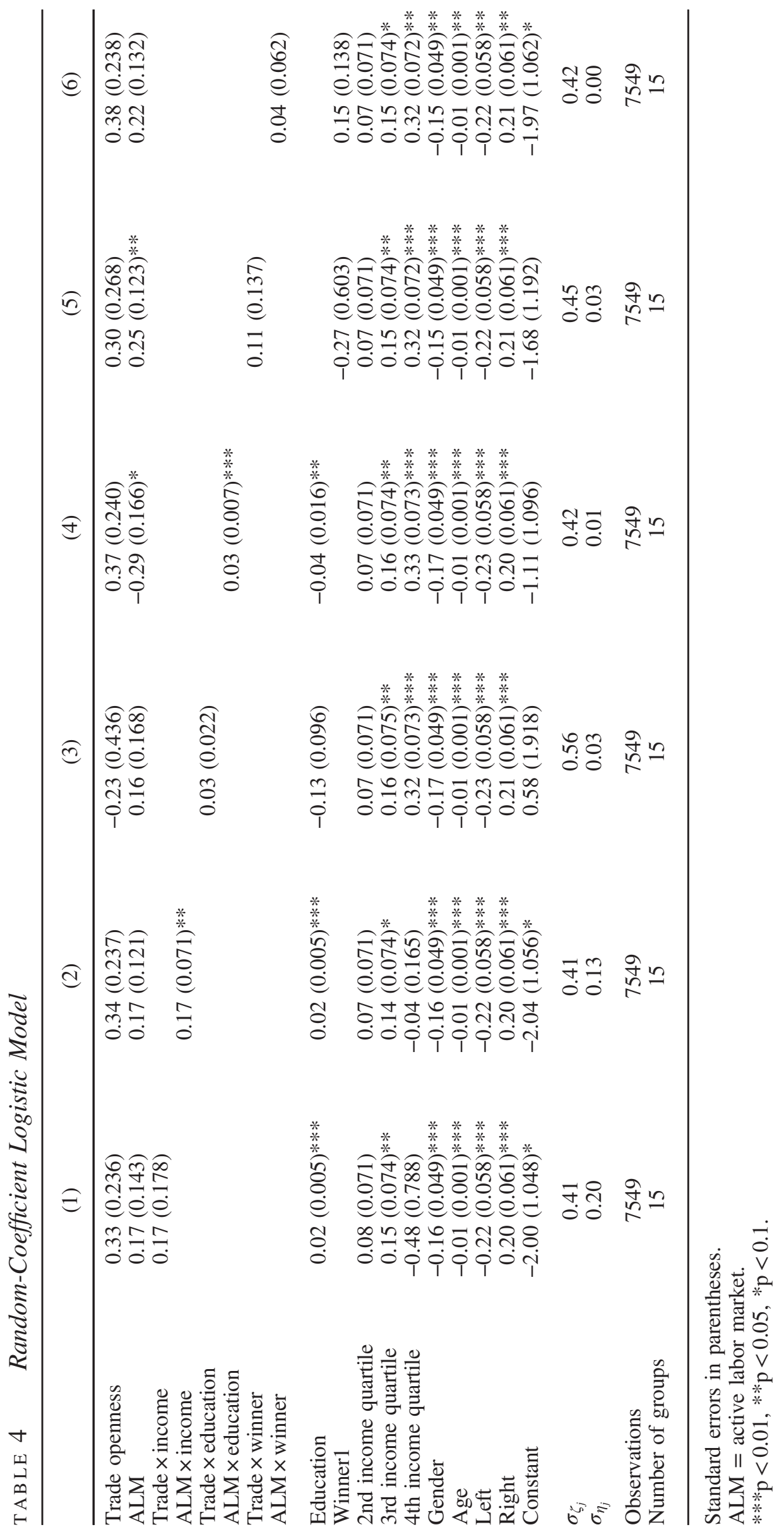




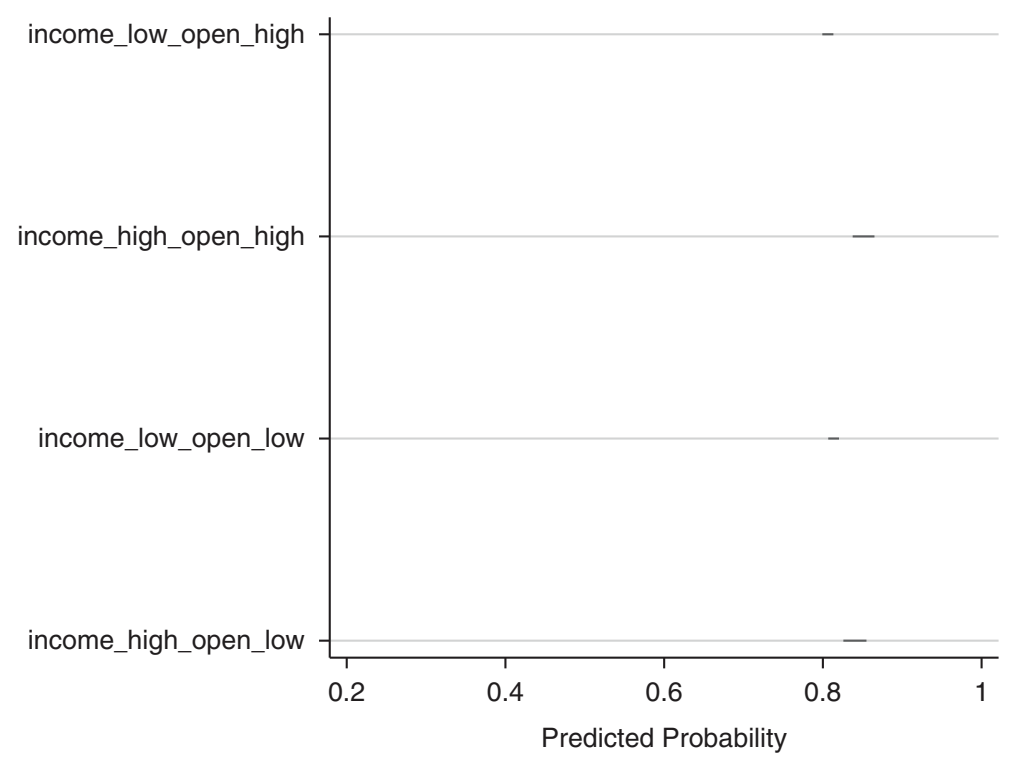

Fig. 4. Simulated predicted probability of seeing globalization as positive given four different combinations of 4th income quartile and trade openness

Note: simulations are for a male individual with a center political attitude. Active labor market, education and age are kept at their median values.

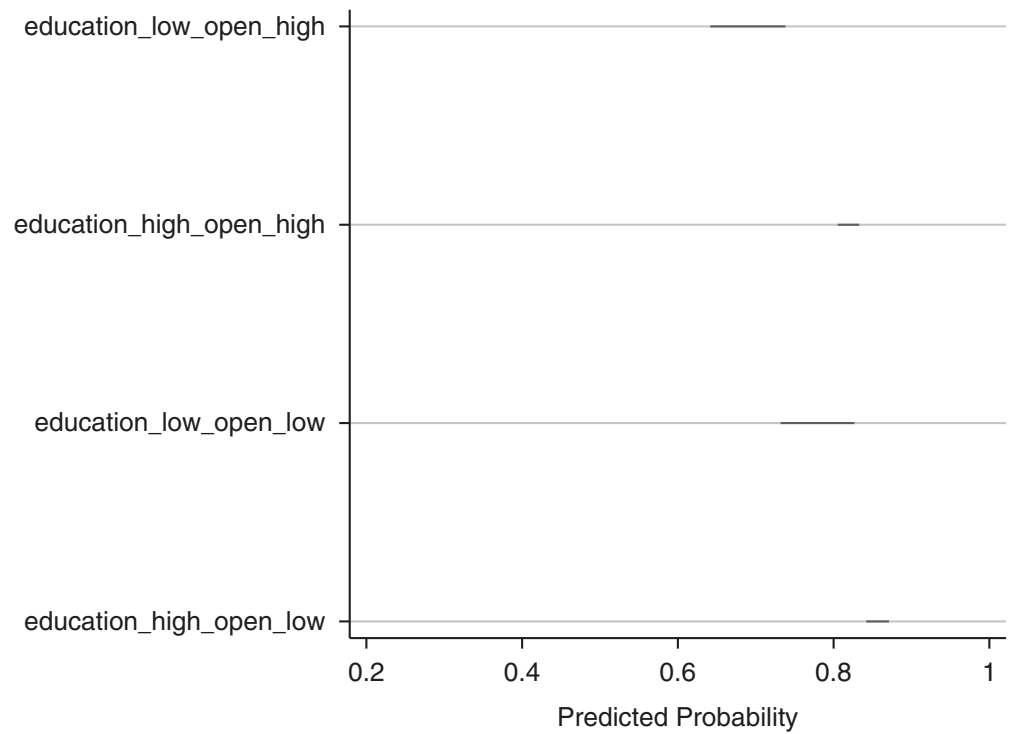

Fig. 5. Simulated predicted probability of seeing globalization as positive given four different combinations of education and trade openness

Note: simulations are for a male individual in the 3rd income quartile with a center political attitude. Active labor market and age are kept at their median values.

in a more negative light. Surprisingly, we do not find a positive reinforcing effect for winners (those having a high level of education), but rather individuals with higher education also see globalization less favorable in comparatively more open countries.

If we now consider whether an individual professionally wins from globalization (Figure 6), we again see the proposed positive reinforcing effect of economic globalization for winners, but this time, we also find that losers in more globalized contexts have a higher probability of seeing globalization as something positive. Moreover, this time the differences between the scenarios is greater than in the previous situations: living in an open country increases the likelihood of 


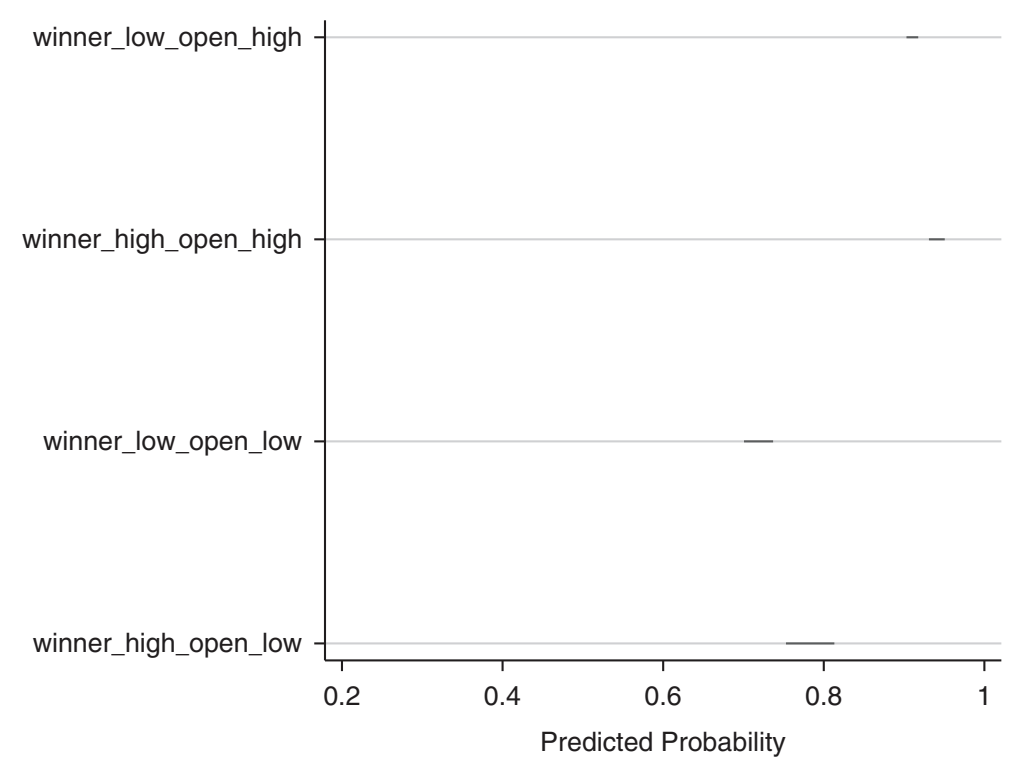

Fig. 6. Simulated predicted probability of seeing globalization as positive given four different combinations of winner and trade openness

Note: simulations are for a male individual in the 3 rd income quartile with a center political attitude. Active labor market and age are kept at their median values.

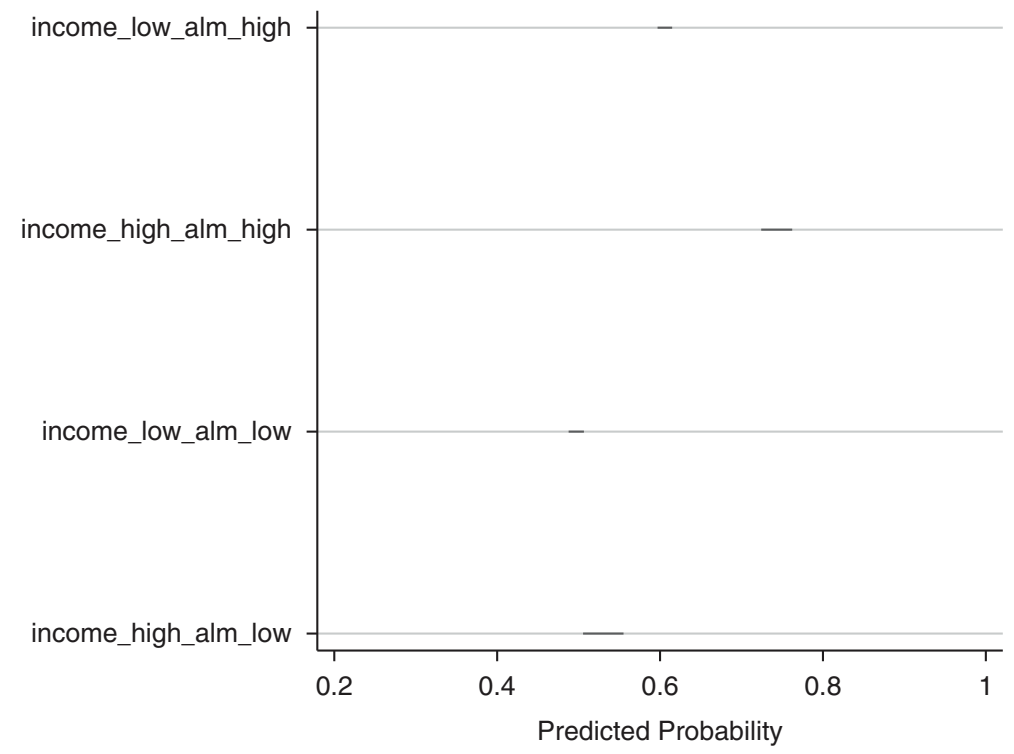

Fig. 7. Simulated predicted probability of seeing globalization as positive given four different combinations of 4th income quartile and active labor market

Note: simulations are for a male individual with a center political attitude. Openness, education and age are kept at their median values.

seeing globalization as something positive for oneself by about 18 percentage points in the case of individuals who should professionally lose from globalization and it increases the likelihood for individuals who should gain from globalization by about 14 percentage points.

Overall, the results lend only mixed support to Hypothesis $3 \mathrm{a}$ in that actual economic globalization indeed reinforces a more negative attitude of globalization losers (when considering education and capital ownership), but also a more positive attitude of globalization for globalization winners (when considering capital ownership and whether the individual professionally gains). A possible explanation for why we do not observe a positive reinforcing 


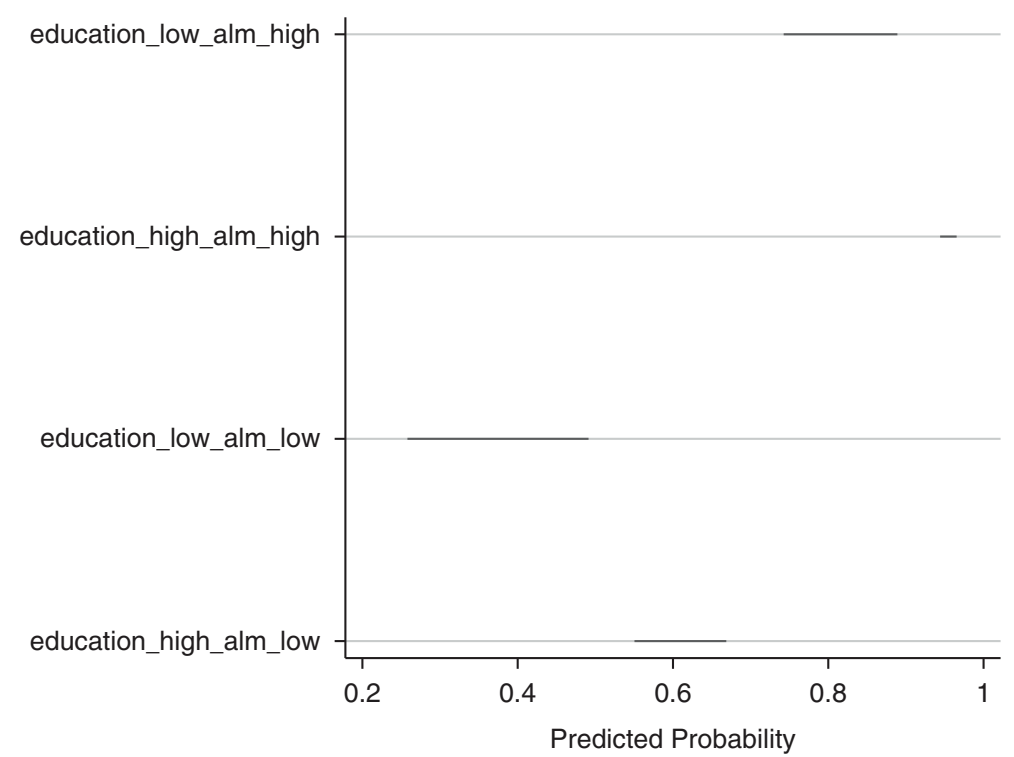

Fig. 8. Simulated predicted probability of seeing globalization as positive given four different combinations of education and active labor market

Note: simulations are for a male individual in the 3 rd income quartile with a center political attitude. Openness and age are kept at their median values.

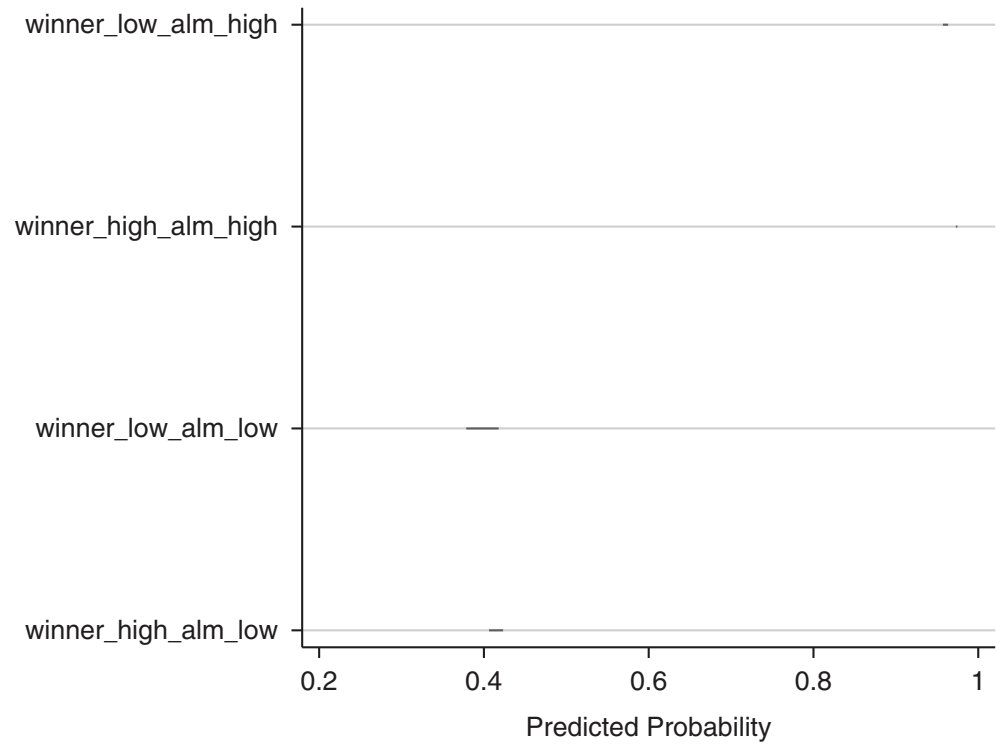

Fig. 9. Simulated predicted probability of seeing globalization as positive given four different combinations of winner and active labor market

Note: simulations are for a male individual in the 3rd income quartile with a center political attitude. Openness and age are kept at their median values.

effect for individuals who are well educated could be a social equity bias. Individuals with high levels of education might perceive globalization as harming not only themselves but also others, and thus might be personally less in favor of globalization in very open countries. In the case of individuals who professionally lose from globalization, we observe a positive instead of a negative reinforcing effect. As we classified winners and losers according to their stated profession and their educational level without having exact data on their sectoral employment, we are hesitant to draw any speculation on the reasons behind this rather surprising effect as it could be partially because of our measurement strategy. 
Turning to the interaction between our factor (capital ownership), skill (education) and profession (professionally winning) measures and active labor market programs as a percentage of government spending (Figures 7-9), we obtain some support for Hypothesis 3b, and see a much clearer picture throughout the different measures.

Generally, compensation seems to be working to the extent that individuals seem to feel less threatened by globalization in countries with higher levels of compensation. In line with our above argument, trade losers (individuals with low levels of income) have a higher probability of seeing globalization as something positive if they live in a country that is characterized by high ALM spending - about 11 percentage points difference. This finding corroborates recent research by Ehrlich and Hearn (2013). In a survey-experimental setting within the United States, they indeed find that knowledge on (trade-)compensatory measures leads to an increase in support for trade for persons that are considered to be losers of globalization because of their low income. Furthermore, they report that knowledge of compensatory programs actually leads to lower support for trade among individuals with high incomes (Ehrlich and Hearn 2013).

Regarding globalization winners' reaction to compensation, however, results from Ehrlich and Hearn's (2013) experimental study within the United States stand in sharp contrast to the results we obtain for the 15 European countries in our sample. The surprising finding in light of our theoretical argument is that the compensation effect also holds for those individuals who can be seen as winners of globalization (capital ownership (belonging to the 4th income quartile)) here the likelihood of seeing globalization as positive is estimated to be about 22 percentage points higher. Following our argument we should have observed that their attitude toward globalization is not contingent on the level of welfare state generosity. We have proposed that as they are winning from globalization, they need not rely on government compensation. However, empirically these individuals, similar to the individuals losing from globalization, feel more inclined to embrace globalization if they live in a country that offers a strong governmentsponsored safety net. These results are supported if we look at the other two interaction effects as displayed in Figure 8 (highly educated individuals) and in Figure 9 (professional trade winner). Again, in line with our argument, trade losers (individuals with low levels of education) have a higher probability of seeing globalization as something positive if they live in a country that is characterized by high ALM spending-the likelihood of seeing globalization as positive is estimated to be about 40 percentage points higher for education. As in the case of trade openness, the differences between the various scenarios is greatest in the case of professional trade winners and losers. Here, we estimate the difference between the low and high ALM scenarios to be about 57 percentage points. An explanation for the finding that potential winners from trade are also reinforced in their positive attitude toward globalization in countries with high ALM spending, might be that although winners are not immediately at risk from globalization, they still might be risk averse and like the idea of a potential safety net to hedge against future uncertainty. In addition, their motivations might be that they see such compensation as a necessary means to politically achieve or sustain the internationalization process from which they profit (which follows the embedded liberalism logic, cf. Ruggie 1982; Hays, Ehrlich and Peinhardt 2005; Hays 2009; Ehrlich and Hearn 2013).

To conclude, our results imply only weak support for the implications of the compensation hypothesis as derived in Hypotheses 1 and 2 and some support for the argument that the effect of economic globalization and welfare state generosity is conditional on individual-level characteristics (Hypotheses 3a and 3b). Our first hypothesis is not compatible with the results of our multi-level model as higher economic globalization levels are either not or sometimes positively associated with individual globalization preferences. In contrast, if we consider the effect of welfare state generosity, in the case of active labor market spending we observe that 
individuals living in countries with a stronger social safety net seem to be more in favor of globalization. This result supports Hypothesis 2. If we then condition the effect of actual economic globalization on whether a person wins or loses from globalization, we obtain some interesting results. Actual economic globalization indeed reinforces a more negative attitude of globalization losers (when considering education and capital ownership), but also a more positive attitude of globalization for globalization winners (when considering capital ownership and whether the individual professionally gains). Here, the difference we find between the skill (education) and factor-endowment (income) categorization of winners and losers is interesting and clearly calls for further research into individuals' determinants of globalization preferences. Individuals with a higher level of education might, e.g., understand globalization and its effects on parts of the population in a more nuanced way (Hainmueller and Hiscox 2006) and may thus be triggered by sociotropic thinking (Mansfield and Mutz 2009; Fordham and Kleinberg 2012) or consideration for others. Finally, our results partially support Hypothesis $3 \mathrm{~b}$ as trade losers indeed feel compensated by high active labor market spending and therefore have a much higher likelihood of seeing globalization as something positive compared with those living in a country with a low level of welfare state generosity. Interestingly, this compensatory effect also holds for individuals who are winning from trade and for whom compensation should thus be irrelevant. Again, this finding calls for further research on the exact motivations of winners that then could theoretically be linked to the literature on cross-country differences in the willingness to support the welfare state. This may then also be a test of the validity and universality of the embedded liberalism claim.

\section{Robustness Checks}

In this section we describe various robustness checks we have completed to reassess our results. Following the literature, we replace trade openness with further indicators of economic globalization in order to check the robustness of our results (Garrett and Mitchell 2001; Brady, Beckfield and Seeleib-Kaiser 2005; Dreher, Sturm and Ursprung 2008). In particular, we use FDI net inflows as well as net outflows expressed as a percentage of GDP. The data come from the World Development Indicators (World Bank 2006). Furthermore, we rely on the economic dimension of the KOF globalization index as a more encompassing measure of globalization (Dreher 2006). Finally, instead of using the five-year average of trade openness we employ the yearly change of trade openness. The idea behind this measure is to see whether antiglobalization sentiments are larger in countries that experienced sharp increases in their levels of trade exposure just before the survey.

However, as we can see in Table 5, the results are substantively identical to the results displayed in Table 3. This means that, independent of the measure of globalization, individuals do not perceive globalization more negatively if they are living in countries exposed to more economic openness, as postulated by Hypothesis 1.

In addition, we include two other macro-level covariates, namely economic growth and unemployment. We added these two variables to capture the link between trade exposure and labor market risk. ${ }^{15}$ Both variables show the sign that one would theoretically expect: Higher unemployment is associated with more negative attitudes toward globalization, whereas economic growth is, although not significantly, associated with more positive attitudes toward globalization. However, their inclusion does not alter the substantial results of the other qvariables in the model (see last column in Table 5).

\footnotetext{
15 The data on economic growth is taken from the Penn World Tables (Heston, Summers and Aten 2006) and the data on unemployment from the OECD Statistics Database.
} 


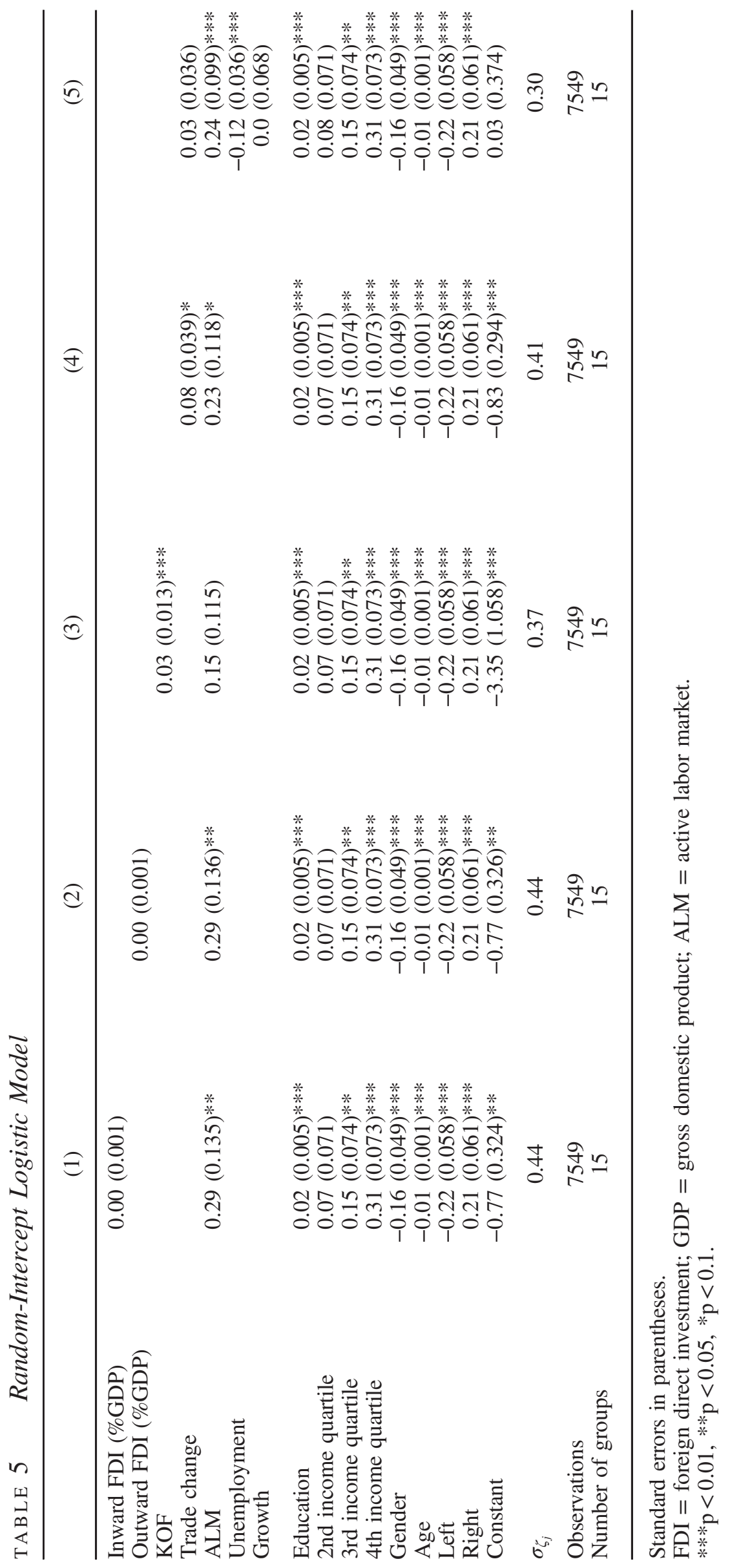


Consequently, these results suggest that, independent of how globalized a country really is, higher unemployment is connected with more negative attitudes toward globalization. This could be indirect evidence for the logic underlying the compensation hypothesis. Individuals might perceive globalization as the reason for the high level of unemployment demanding compensation. However, we cannot be sure as this unemployment result is in line with many other theories on globalization and welfare spending, especially with the argument by Iversen and Cusack (2000). These authors show that the observed growth in government consumption and transfers can be explained as a function of the severity of employment losses in traditional sectors, i.e., internal risk, and not globalization or external risk. More importantly, however, as individual perceptions of globalization do not depend on actual globalization as specified by the compensation hypothesis even after controlling for unemployment, the results in Table 5 are definitely no direct evidence in favor of the compensation hypothesis.

Furthermore, we checked whether our results hold if we control for how well an individual is informed. It could be argued that only well-informed individuals make the connection between actual economic globalization and the compensation granted by the government. Unfortunately, the Eurobarometer data contains only one question that asks whether individuals use the newspaper to obtain information on the European Union. Although this variable is far from optimal, it does not change our results as can be seen in Table 6. Interestingly, the results suggest that more informed individuals are more likely to see globalization in a positive light. In this regression model, we additionally control for whether a respondent indicated that taxation is an important issue to him or her. This could potentially be important as globalization winners could be less supportive of a generous welfare state as they must pay for it through higher taxes without ever accessing it. However, this does not alter the effect of compensation on individuals' attitudes toward globalization.

As described above, we created four different variables to capture whether someone's profession should lose or gain from trade, as predicted by the sector-specific trade model. When constructing the winner variable, we relied on two pieces of information: a person's profession and her

TABLE 6 Random-Intercept Logistic Model

(1)

(2)

(3)

(4)

\begin{tabular}{|c|c|c|c|c|}
\hline $\begin{array}{l}\text { Trade openness } \\
\text { ALM } \\
\text { Unemployment spending }\end{array}$ & $\begin{array}{l}0.36(0.237) \\
0.21(0.124)^{*}\end{array}$ & $\begin{array}{c}0.37(0.239) \\
0.23(0.124)^{*}\end{array}$ & $-0.03(0.072)$ & $-0.02(0.074)$ \\
\hline $\begin{array}{l}\text { Education } \\
\text { Winner } \\
\text { 2nd income quartile } \\
\text { 3rd income quartile } \\
\text { 4th income quartile } \\
\text { Gender } \\
\text { Age } \\
\text { Left } \\
\text { Right } \\
\text { Information on European Union } \\
\text { Taxation important } \\
\text { Constant }\end{array}$ & $\begin{array}{r}0.07(0.071) \\
0.13(0.075)^{*} \\
0.28(0.073)^{* * *} \\
-0.15(0.049)^{* * *} \\
-0.01(0.001)^{* * *} \\
-0.22(0.058)^{* * *} \\
0.21(0.061)^{* * *} \\
0.18(0.052)^{* * *} \\
0.15(0.092) \\
-2.24(1.058)^{* *}\end{array}$ & $\begin{array}{r}0.22(0.058)^{* * *} \\
0.06(0.071) \\
0.13(0.075)^{*} \\
0.29(0.073)^{* * *} \\
-0.14(0.049)^{* * *} \\
-0.01(0.001)^{* * *} \\
-0.21(0.058)^{* * *} \\
0.21(0.061)^{* * *} \\
0.19(0.052)^{* * *} \\
0.14(0.092) \\
-2.07(1.064)^{*}\end{array}$ & $\begin{array}{c}0.06(0.071) \\
0.12(0.075) \\
0.28(0.073)^{* * *} \\
-0.15(0.049)^{* * *} \\
-0.01(0.001)^{* * *} \\
-0.22(0.058)^{* * *} \\
0.21(0.061)^{* * *} \\
0.18(0.052)^{* * *} \\
0.15(0.092) \\
-2.09(1.148)^{*}\end{array}$ & $\begin{aligned} & 0.22(0.058) * * * \\
& 0.06(0.071) \\
& 0.12(0.075)^{*} \\
& 0.29(0.073) * * * \\
&-0.14(0.049)^{* * *} \\
&-0.01(0.001)^{* * *} \\
&-0.21(0.058)^{* * *} \\
& 0.21(0.061)^{* * *} \\
& 0.19(0.052) * * * \\
& 0.14(0.092) \\
&-1.90(1.174)\end{aligned}$ \\
\hline$\sigma_{\zeta_{j}}$ & 0.42 & 0.43 & 0.46 & 0.47 \\
\hline $\begin{array}{l}\text { Observations } \\
\text { Number of countries }\end{array}$ & $\begin{array}{l}7549 \\
15\end{array}$ & $\begin{array}{c}7549 \\
15\end{array}$ & $\begin{array}{l}7549 \\
15\end{array}$ & $\begin{array}{l}7549 \\
15\end{array}$ \\
\hline
\end{tabular}

Standard errors in parentheses.

$* * * \mathrm{p}<0.01, * * \mathrm{p}<0.05, * \mathrm{p}<0.1$. 
TABLE 7 Random-Intercept Logistic Model

(1)

$$
\begin{gathered}
0.37(0.239) \\
0.24(0.124)^{*} \\
0.27(0.057) * * * \\
\\
0.05(0.072) \\
0.12(0.075) \\
0.27(0.074)^{* * *} \\
-0.16(0.049)^{* * *} \\
-0.01(0.002)^{* * *} \\
-0.22(0.058)^{* * *} \\
0.21(0.061)^{* * *} \\
-2.10(1.063)^{* *} \\
0.43 \\
7549 \\
15
\end{gathered}
$$$$
\text { ALM }
$$

Winner (no retired)

Winner (no students)

Winner (no retired + no students)

2nd income quartile

3 rd income quartile

4 th income quartile

Gender

Age

Left

Right

Constant

$\sigma_{\zeta_{j}}$

Observations

Number of groups
(2)

(3)
$0.37(0.237)$
$0.25(0.123) * *$
$0.08(0.057)$
$0.08(0.072)$
$0.16(0.075) * *$
$0.34(0.073) * * *$
$-0.15(0.049) * * *$
$-0.01(0.002) * * *$
$-0.21(0.058) * * *$
$0.21(0.061) * * *$
$-1.89(1.056)^{*}$
0.42
7549
15

$0.37(0.238)$

$0.25(0.124)^{* *}$

$0.12(0.054)^{* *}$

$0.07(0.072)$

$0.14(0.075)^{*}$

$0.31(0.075) * * *$

$-0.16(0.049) * * *$

$-0.01(0.001) * * *$

$-0.21(0.058) * * *$

$0.21(0.061) * * *$

$-1.92(1.058) *$

0.42

7549

15

Standard errors in parentheses.

$* * * \mathrm{p}<0.01, * * \mathrm{p}<0.05, * \mathrm{p}<0.1$.

education level. However, given this information, it is not entirely clear whether students as well as retired persons should be counted as winners or losers of globalization. Until now, we have used the variable that includes both students and retired persons as globalization winners. To test whether the results are sensitive to this decision, we created three additional variables counting either the students or the retired or both to the losers of globalization. As the results in Table 7 show, the effect of the winner variable stays positive in all cases. However, if we exclude students from the winner category, the effect turns insignificant (this is not the case if both retirees and students are excluded). Hence, the above results stating that winners from globalization tend to perceive globalization as something beneficial needs to be interpreted with some caution.

Finally, we cross-checked our results using a two-step procedure instead of a random-intercept model to explain individual attitudes toward globalization. This approach, as indicated by its name, consists of two steps to estimate the effect of globalization on citizens' attitudes. In a first step, all individual-level characteristics are included in the regression. In a second step, the coefficients of the first regression equation are then used as the dependent variable to see how country-level characteristics such as the level of economic globalization influence individuals' attitudes: this approach of using two steps in contrast to a one-step hierarchical model is specially suitable for models in which the first equation consists of a non-linear model (Achen 2005). However, the advantage of the two-step procedure, which lies in the convenience of allowing coefficients to vary with any higher level variables, comes at the price of being less efficient (Leoni 2010).

Using this two-step procedure instead of the models shown above, does, however, not change our results in any substantive way. ${ }^{16}$ This lends further support to the various conclusions drawn from our earlier results.

\section{CONCLUSION}

The aim of this paper was twofold, we first provided a rigorous and extensive analysis on the conditional effect of country-level economic globalization and country-level compensation on

\footnotetext{
${ }^{16}$ As reporting the results requires numerous tables, they are available from the authors on request.
} 
individuals' perception of globalization. This analysis tests some implications of the two macro-micro links underlying the compensation hypothesis. In particular, we evaluated whether individuals who are living in more globalized countries perceive globalization as more threatening as would be in line with the compensation hypothesis. In our analyses, however, we have found that actual economic globalization (measured by either trade openness, FDI in- and outflows or the KOF economic globalization index) either does not play a significant role for people's perception at all or positively affects individual trade-level attitudes. The latter is the opposite effect than one should expect according to the logic underlying the compensation hypothesis, which postulates that individuals should react to increased levels of economic globalization with more negative feelings. Furthermore, we assessed whether governments are able to cushion their citizens from the perceived negative consequences of globalization by providing a stronger social safety net. As far as our second hypothesis is concerned, we stipulated that the granting of benefits for losers of globalization should help people to view globalization as a necessary and good development, and-in line with the claims of embedded liberalism - we hypothesized that this would lead to a higher propensity to see globalization in a positive way. This is indeed the case if the generosity of the welfare state is measured using government spending on active labor market programs. However, for our other measuregovernment spending on unemployment-we see that the granting of compensation is not connected to the perception of globalization. This is an interesting result with respect to policy implications from our research. Thus, it seems that spending on concrete programs to actively help people obtain necessary qualifications for a changing labor market leaves people with a more positive view of globalization compared with government's efforts to increase transfer payments such as unemployment benefits. Turning now to the individual level, we generally see that, in line with standard trade theory, capital-owning individuals are more in favor of globalization. Similarly, highly educated persons and individuals, whose profession should win from globalization, are also more likely to see globalization as something beneficial. In contrast, women, the elderly and individuals with left-wing political attitudes tend to be less favorable toward globalization.

Second, we are interested to what extent these individual globalization preferences are then contingent on whether the individuals are winning or losing from trade. In this contribution, we use standard trade theory models to classify who would be a globalization winner or loser. Thus, based on their socio-economic and vocational characteristics we hypothesized different levels of globalization support, given an individual's contextual settings (national level) as well as an individual's endowments (individual level). To this end, we then condition the effect of actual economic globalization/compensation granted on whether a person wins or loses from globalization. For Hypothesis 3a, our findings partially support our theoretical arguments. Actual economic globalization indeed reinforces a more negative attitude of globalization losers (when considering education and capital ownership), but also a more positive attitude of globalization for globalization winners (when considering capital ownership and whether the individual professionally gains). Here, the difference we find between the skill (education) and factor-endowment (income) categorization of winners and losers is interesting and clearly calls for further research into individuals' determinants of globalization preferences.

Finally, our results partially support Hypothesis $3 \mathrm{~b}$ as trade losers indeed feel compensated by high active labor market spending and therefore have a much higher likelihood of seeing globalization as something positive than if they live in a country with a low level of welfare state generosity. Interestingly, this compensatory effect also holds for individuals who are winning from trade and for whom compensation should thus be irrelevant. This is puzzling as individuals who are winning from trade are also potentially those individuals who are paying 
most for the existence of a generous social safety through taxes. Hence, living in a country with a strong social safety net should, following this perspective, rather decrease their positive perception on trade. In contrast, and in our view, more likely are two considerations. First, it could be that these individuals were motivated by social equity concerns and might value the fact that their government looks after potential losers of globalization even if they themselves might never belong to this category. Or, second, their motivations might be that they see such compensation as a necessary means to politically achieve or sustain the internationalization process from which they profit.

In our opinion, our results show that the compensation hypothesis typically presented in the literature might fall short of correctly specifying individual-level reactions to globalization. Instead our results hint to a conditional compensation hypothesis in the sense that it depends on a person winning or losing from globalization whether she perceives globalization as something threatening or not. Hence, actual globalization does not result in a general reaction by a country's citizens but depending on an individual's personal situation results in a positive or negative sentiment. This further explains why ALM spending, a very targeted way to measure compensation, seems to provide a safety net, whereas we do not observe this compensatory effect for general welfare spending. Moreover, our results suggest that globalization winners, although they in general like globalization, are still inclined to accept ALM spending as a necessary form of compensation in order to sustain the internationalization process from which they profit. Above all, our results indicate that more research into the determinants of individual trade preferences are needed, especially to correctly reveal along which economic or potentially non-economic dimension individuals can be grouped into winners and losers of globalization. Although in this paper we have opted to concentrate on the economic explanations for individual trade preferences, our general theoretical argument is not necessarily confined to economic explanations. One possible extension would be to employ a different (non)-economic conceptualization of winners and losers of the globalization process within our framework stressing the importance of contexts and context-conditional effects in the formation of people's trade attitudes.

Overall, our results are the first attempt to capture the link between the macro-level of actual economic globalization and the micro-level of citizens' attitude toward globalization in a multilevel setting. We have brought some light into the debate whether actual economic globalization and compensation really do affect individual's preferences. For actual economic globalization people do not seem to necessarily make the connection, however, as far as a compensation aspect granted by the government is concerned (ALMP's), individuals in countries operating such programs are more in favor of globalization and feel compensated. For the findings on the individual-level interaction, the result that also winners of globalization have a more positive view on globalization in countries with a higher level of welfare state generosity is puzzling but hints to a potentially risk avoiding or social equity behavior on their part. In this way, this paper intends to be a first grasp of how macro-level phenomena such as globalization or the granting of a social safety net influence individual-level perception, given different individual-level characteristics such as education or income, with further research having to go into more detail on testing alternative non-economic, e.g., social psychological factors.

\section{ACKNOWLEDGEMENT}

We would like to thank Michael Bechtel, Thomas Bernauer, Vally Koubi, Carmela Lutmar, Peter Selb, Dustin Tiengley, Vera Tröger, Stefanie Walter, Fabio Wasserfallen and three anonymous reviewers for their valuable comments and research advice. 


\section{REFERENCES}

Achen, Christopher. 2005. 'Two-Step Hierarchical Estimation: Beyond Regression Analysis'. Political Analysis 13(4):447-56.

Baker, Andy. 2008. 'Public Opinion and the Compensation Hypothesis'. Paper Presented at the Annual Meeting of the International Political Economy Society, November 14-15, 2008. University of Pennsylvania, Philadelphia, PA.

Bechtel, Michael, Jens Hainmueller, and Yotam Margalit. 2014. 'Preferences Toward International Redistribution: The Divide Over the Eurozone Bailouts'. American Journal of Political Science 58:835-56.

Boix, Carles. 2004. 'Between Redistribution and Trade: The Political Economy of Protectionism and Compensation'. In P. K. Bardhan, S. Bowles and M. Wallerstein (eds), Globalization and Egalitarian Redistribution. Princeton, NJ: Princeton University Press and Russell Sage Foundation.

Brady, David, Jason Beckfield, and Martin Seeleib-Kaiser. 2005. 'Economic Globalization and the Welfare State in Affluent Democracies, 1975-2001'. American Sociological Review 70:921-48.

Burgoon, Brian. 2001. 'Globalization and Welfare Compensation: Disentangling the Ties that Bind'. International Organization 55(3):509-51.

Burgoon, Brian, and Michael Hiscox. 2008. 'The Gender Divide Over International Trade: Why Do Men and Women Have Different Views About Openness to the World Economy'? Working Paper, SSRN. Cambridge, MA: Harvard University.

Carpini, Michael X.D., and Scott Keeter. 1993. 'Measuring Political Knowledge: Putting First Things First'. American Journal of Political Science 37(4):1179-206. 1997. What Americans Know About Politics and Why It Matters. New Haven, CT: Yale University Press.

Cusack, Thomas, Torben Iversen, and Philipp Rehm. 2005. 'Risks at Work: The Demand and Supply Sides of Government Redistribution'. Discussion Paper No. SP II 2005-15, Wissenschaftszentrum, Berlin.

Down, Ian. 2007. 'Trade Openness, Country Size and Economic Volatility: The Compensation Hypothesis Revisited'. Business and Politics 9(2):1-20.

Dreher, Axel. 2006. 'Does Globalization Affect Growth? Evidence from a New Index of Globalization'. Applied Economics 38(10):1091-110.

Dreher, Axel, Jan-Egbert Sturm, and Heinrich Ursprung. 2008. 'The Impact of Globalization on the Composition of Government Expenditures: Evidence from Panel Data'. Public Choice 134(3):263-92.

The Economist. 2009. 'The Return of Economic Nationalism'. The Economist, 5 February, Available at http://www.economist.com/node/13061443, accessed 26 March 2009.

Ehrlich, Sean D., and Eddie Hearn. 2013. 'Does Compensating the Losers Increase Support for Trade? An Experimental Test of the Embedded Liberalism Thesis'. Foreign Policy Analysis 10(2):1-16.

Eurobarometer. 2004. 'Standard Eurobarometer Survey'. Available at http://ec.europa.eu/public_opinion/ standard_en.htm, accessed 26 March 2009.

Fordham, Benjamin O. 2008. 'Economic Interests and Public Support for American Global Activism'. International Organization 62(1):163-82.

Fordham, Benjamin O., and Katja B. Kleinberg. 2012. 'How Can Economic Interests Influence Support for Free Trade?'. International Organization 66(2):311-28.

Galston, William. 2001. 'Political Knowledge, Political Engagement, and Civic Education'. Annиal Review of Political Science 4(1):217-34.

Garrett, Geoffrey, and Deborah Mitchell. 2001. 'Globalization, Government Spending and Taxation in the OECD'. European Journal of Political Research 39(2):145-77.

Gelman, Andrew, and Jennifer Hill. 2007. Data Analysis Using Regression and Multilevel/Hierarchical Models. Cambridge, UK: Cambridge University Press.

Genschel, Philipp. 2004. 'Globalization and the Welfare State: A Retrospective'. Journal of European Public Policy 11(4):613-36.

Hainmueller, Jens, and Michael J. Hiscox. 2006. 'Learning to Love Globalization: Education and Individual Attitudes Toward International Trade'. International Organization 60(2):469-98.

Hays, Jude. 2009. Government Spending and Public Support for Trade in the OECD. Oxford: Oxford University Press. 
Hays, Jude, Sean Ehrlich, and Clint Peinhardt. 2005. 'Government Spending and Public Support for Trade in the OECD: An Empirical Test of the Embedded Liberalism Thesis'. International Organization 59(2): 473-94.

Heston, Alan, Robert Summers, and Bettina Aten. 2006. 'Penn World Table Version 6.2'. Center for International Comparisons of Production, Income and Prices, University of Pennsylvania, Philadelphia.

Hicks, Alexander, and Duane Swank. 1992. 'Politics, Institutions and Welfare Spending in Industrialized Democracies'. American Political Science Review 86(3):658-74.

Huber, Evelyne, Charles Ragin, and John Stephens. 1993. 'Social Democracy, Constitutional Structure and the Welfare State'. American Journal of Sociology 99(3):711-49.

Iversen, Torben, and Thomas Cusack. 2000. 'The Causes of Welfare State Expansion: Deindustrialization or Globalization?' World Politics 52(3):313-49.

Kittel, Bernhard, and Hannes Winner. 2005. 'How Reliable is Pooled Analysis in Political Economy? The Globalization-Welfare State Nexus Revisited'. European Journal of Political Research 44(2):269-93.

Leoni, Eduardo. 2010. 'Analyzing Multiple Surveys: Results from Monte Carlo Experiments'. Available at http://eduardoleoni.com/.

Mansfield, Edward, and Diana Mutz. 2009. 'Support for Free Trade: Self-Interest, Sociotropic Politics, and Out-Group Anxiety'. International Organization 63(3):425-57.

Mayda, Anna Maria, and Dani Rodrik. 2005. 'Why Are Some People (and Countries) More Protectionist Than Others?'. European Economic Review 49(6):1393-430.

Meinhard, Stephanie, and Niklas Potrafke. 2012. 'The Globalization-Welfare State Nexus Reconsidered'. Review of International Economics 20(2):271-87.

Oatley, Thomas. 2010. International Political Economy. Boston, MA: Longman.

Pierson, Paul. 2001. 'Post-Industrial Pressures on the Mature Welfare States'. In P. Pierson, (ed.), The New Politics of the Welfare State, 80-105. Oxford: Oxford University Press.

Plümper, Thomas, Vera Tröger, and Philip Manow. 2005. 'Panel Data Analysis in Comparative Politics: Linking Method to Theory'. European Journal of Political Research 44(2):327-54.

Potrafke, Niklas. 2009. 'Did Globalization Restrict Partisan Politics? An Empirical Evaluation of Social Expenditures in a Panel of OECD Countries'. Public Choice 140(1-2):105-24.

Rabe-Hesketh, Sophia, and Anders Skrondal. 2009. Multilevel and Longitudinal Modeling Using Stata. College Station, TX: Stata Press.

Rehm, Philipp. 2009. 'Risks and Redistribution: An Individual-Level Analysis'. Comparative Political Studies 42(7):855-81.

Rodrik, Dani. 1997. Has Globalization Gone Too Far? Washington, DC: Institute for International Economics.

— . 1998. 'Why Do More Open Economies have Bigger Governments?'. Journal of Political Economy 106(5):997-1032.

Ruggie, John G. 1982. 'International Regimes, Transactions, and Change: Embedded Liberalism and the Post-War Economic Regimes'. International Organization 36(2):195-232.

Scheve, Kenneth F., and Matthew J. Slaughter. 2001. 'What Determines Individual Trade-Policy Preferences?'. Journal of International Economics 54(2):267-92.

- 2004. 'Economic Insecurity and the Globalization of Production'. American Journal of Political Science 48(4):662-74.

- 2006. 'Public Opinion, International Economic Integration, and the Welfare State'. In Pranab, K. Bardhan, Samuel Bowles and Michael Wallerstein (eds), Globalization and Egalitarian Redistribution, 217-60. Princeton, NJ: Princeton University Press.

Sears, David O., and Carolyn L. Funk. 1990. 'The Limited Effect of Economic Self-Interest on the Political Attitudes of the Mass Public'. Journal of Behavioral Economics 19(3):247-71.

Steenbergen, Marco R., and Bradford S. Jones. 2002. 'Modeling Multilevel Data Structures'. American Journal of Political Science 46(1):218-37.

Walter, Stefanie. 2010. 'Globalization and the Welfare State: Testing the Microfoundation of the Compensation Hypothesis'. International Studies Quarterly 54(2):403-26.

World Bank. 2006. 'World Development Indicators'. Available at http://go. worldbank.org/U0FSM7AQ40, accessed 26 March 2009. 